\title{
Hypothalamic control of prolactin release in the rainbow trout, Salmo gairdneri: in vitro studies
}

\author{
Francis Gonnet ${ }^{1}$, Alain Barret ${ }^{2}$, Dominique Grouselle ${ }^{2}$ and Patrick Prunet ${ }^{1 *}$ \\ ${ }^{1}$ Laboratoire de Physiologie des Poissons, INRA, Campus de Beaulieu, 35042 Rennes Cedex, France; \\ ${ }^{2}$ Groupe de Neuroendocrinologie cellulaire, Collège de France, 11 Place Marcelin-Berthelot, 75231 Paris, \\ France.
}

Keywords: prolactin, perifusion, pituitary, hypothalamus, rainbow trout

\begin{abstract}
Hypothalamic control of prolactin (PRL) release in immature rainbow trout Salmo gairdneri was investigated using an in vitro perifusion system of the rostral pars distalis. Hypothalamic extract of trout induced a dosedependent stimulation of PRL release. A similar effect was observed when infusing the medium from a $24 \mathrm{~h}$ static incubation of the hypothalamus. Extracts from different control tissues (muscle, liver, gut) did not change in vitro release, thus confirming the specificity of this stimulatory effect. Hypothalamic extract from adult male rat, known to contain PRL release inhibiting factors, stimulated in vitro PRL secretion in rainbow trout. This suggests that PRL cells are predominantly influenced by PRL releasing factors. Measurement of TRH and serotonin content in trout hypothalamus indicated consistent physiological levels of these two factors. HPLC studies of hypothalamic extract showed that immunoreactive - TRH eluted at the same place as labelled TRH standard. Moreover, pizotifen, a serotonin antagonist, partially inhibited the stimulation observed with trout hypothalamic extract. These results suggest that, in immature rainbow trout, PRL release is under stimulatory hypothalamic control and that serotonin and probably TRH play a major role in this control.
\end{abstract}

\section{Introduction}

It is generally accepted that in most teleost species prolactin (PRL) secretion is primarily under inhibitory control of the hypothalamus (Ball et al. 1972; Schreibman and Holtzman 1975; Ball 1981; Peter and Fryer 1983). Evidence comes from histological studies of ectopically transplanted pituitaries which showed increased activity (Ball et al. 1972; Holmes and Ball 1974; Leatherland 1970; Nagahama et al. 1974). Moreover, since the pioneer work of Sage (1966), numerous in vitro studies indicate that PRL cells remain active during static culture, thus confirming a hypothalamic inhibitory control by neural factors (see reviews Ball 1981; Clarke and Bern 1980). Involvement of catecholamines, probably dopamine as the PRL inhibitory factor (PIF) has been demonstrated in several teleost species (Zambrano et al. 1973; Wigham et al. 1975, 1977; Nagahama et al. 1975; Olivereau 1975). Histochemical studies of pituitary innervation by catecholominergic fibers support such involvement (Follenius 1972; Batten and Ball 1977; Kah et al. 1986). Somatostatin has also been suggested as an important inhibitory factor in other teleost species (Grau et al. 1982; Batten and Wigham 1984; Grau et al.

* To whom all correspondence should be addressed. 
1985). However hypothalamic stimulatory factors (PRF) may also act on PRL cell activity as shown in eel (Hall and Chadwick 1978, 1979) and different factors such as serotonin or TRH have been suggested to account for this PRF activity (Olivereau and Olivereau 1979; Hall and Chadwick 1983).

Hypothalamic control of PRL release in salmonids has received little attention. In rainbow trout, transplanted PRL cells appeared less active than the in situ gland suggesting a stimulatory control (Leatherland and Lin 1976) which is in agreement with recent studies on PRL release during long-term incubation of chum salmon pituitaries (Suzuki et al. 1987). The recent development and validation of an in vitro perifusion technique for rostral pars distalis fragments (Gonnet et al. 1988) led us to investigate the effect of hypothalamic extract on PRL release in immature rainbow trout. Moreover, we have tried to characterize the neuroendocrine factor(s) involved in such hypothalamic control.

\section{Materials and methods}

\section{Animals}

Immature rainbow trout Salmo gairdneri (50$250 \mathrm{~g}$ ) were purchased from a hatchery (Gournaysur-Aronde) and kept in recirculating tap water (13 $\pm 1^{\circ} \mathrm{C}$ ) in the laboratory under natural photoperiod. The trout were decapitated between 08.00 and $09.00 \mathrm{~h}$ and the rostral partes distales (RPD) were dissected under a dissecting microscope and preincubated in perifusion medium. The medium consisted of Ringer's solution $(\mathrm{NaCl} 140 \mathrm{mM}, \mathrm{KCl}$ $2 \mathrm{mM}, \mathrm{CaCl}_{2} 2 \mathrm{mM}$, Hepes $15 \mathrm{mM}$ ) gassed with $95 \% \mathrm{O}_{2}: 5 \% \mathrm{CO}_{2}$. Immediately before use the solution was supplemented with $2.5 \mathrm{~g} / 1$ glucose and $0.3 \mathrm{~g} / 1$ bovine serum albumin (fraction $\mathrm{V}$, Sigma). The $\mathrm{pH}$ was adjusted to 7.4 and the osmotic pressure was $300 \mathrm{mOsm} / \mathrm{kg}$.

\section{Perifusion}

The perifusion system employed in this study has been previously described (Gonnet et al. 1988a).
Briefly, 3-5 rostral lobes were suspended in BioGel P2 beads in siliconized glass-columns $(0.9 \times$ $12 \mathrm{~cm})$ and perifused at constant flow rate $(0.2 \mathrm{ml} /$ min) and temperature $\left(15 \pm 1^{\circ}\right)$. After a 90 minute equilibration period, test substances freshly dissolved in the perifusion medium were infused at the same flow rate. Samples were collected at 7.5 min intervals during stabilization periods or 2.5 min intervals during infusion of secretagogues. Hormone levels were measured on the day of perifusion or samples were frozen at $-20^{\circ} \mathrm{C}$ until assay. PRL secreted from rainbow trout RPD was determined using a salmon PRL RIA according to the techniques described by Prunet et al. (1985). This RIA has been demonstrated to be specific for measurement of PRL in rainbow trout (Hirano et al. 1985; Prunet et al. 1985). The sensitivity of the assay was estimated to be $0.4 \mathrm{ng} / \mathrm{ml}$. All experiments were repeated at least 3 times. The PRL concentration was expressed as percentage of the basal value $(100 \%)$ calculated as the mean of 3 samples $(22.5 \mathrm{~min})$ taken just before the infusion of the secretogogues. Statistical differences of PRL levels were tested by Student's t test.

\section{Preparation of extracts and materials}

Hypothalami were dissected under a dissecting microscope at $4^{\circ} \mathrm{C}$ and homogenized using a Polytron homogenizer in $0.1 \mathrm{~N} \mathrm{HCl}$ (1 hypothalamus/ $\mathrm{ml})$. The homogenate was centrifuged $(3,000 \times$ $\mathrm{g}$ for $30 \mathrm{~min}$ ) and the supernatant was filtered through a $0.22 \mu \mathrm{m}$ filter (Millex, Millipore) before dilution in the incubation medium. The $\mathrm{pH}$ was adjusted to 7.4 and the osmotic pressure was maintained at $300 \mathrm{mOsm} / \mathrm{kg}$. Extracts from control tissues (gut, liver, muscle) were prepared using the same protocol. The concentration of tissue extract in all experiments were expressed as tissue equivalents. One equivalent is comparable to $1 \mathrm{mg}$ wet weight of tissue (the approximate weight of trout hypothalamus) $/ \mathrm{ml}$. In some experiments, 5 hypothalami were incubated statically in $5 \mathrm{ml}$ of perifusion medium for $24 \mathrm{~h}$ at $12^{\circ} \mathrm{C}$ and this medium was further tested in our perifusion system. Pizotifen was purchased from Sandoz Laboratory (Basel, Switzerland). 


\section{Measurement of serotonin and TRH content}

For serotonin determination, hypothalami were extracted in $0.4 \mathrm{~N} \mathrm{HCl}$ with $50 \mathrm{mM} \beta$-mercaptoethanol using a sonicator. After centrifugation $(3,000$ $\times \mathrm{g}$ for $20 \mathrm{~min}$ ). The supernatant was neutralized using $2 \mathrm{M}$ potassium acetate. Serotonin concentrations were determined by HPLC according to the technique of Graffeo et al. (1976). Measurement of TRH in extracts of hypothalamic tissue was made according to the following protocol: 5 hypothalami were homogenized in a methanol acid solution (methanol $75 \%$, acetic acid $6 \%$ ) and further extracted using a sonicator. After centrifugation $(2,000 \times \mathrm{g}$ for $20 \mathrm{~min})$ the supernatant was evaporated and the pellet was kept for protein and TRH measurement. TRH concentrations were estimated by RIA as previously described: the radioimmunoassay was performed using an immune serum antiTRH with high specificity at a final dilution of 1:150,000 and monoiodo $\left(\left[^{125} \mathrm{I}\right] \mathrm{His}^{2}\right) \mathrm{TRH}$ purified by TLC as a tracer (Grouselle et al. 1982). The sensitivity of the method was around 4 fmoles. Other hypothalamic extracts were analyzed by reverse-phase HPLC using a LKB liquid chromatograph. A C18 ultrasphere IP $(4.6 \times 150 \mathrm{~mm}, 5 \mu)$ was run isochratically using $1.5 \%$ acetonitrile, TFA $0.1 \%$ in $15 \mathrm{mM}$ ammonium acetate $\mathrm{pH} 4$. Suitable standard ( ${ }^{3} \mathrm{H}$-Pro)-TRH was run to determine the retention time of authentic TRH (Burgus et al. 1977).

\section{Results}

\section{Effect of hypothalamic extracts on PRL secretion}

As shown in Fig. 1, infusion of hypothalamic extract from immature rainbow trout for $5 \mathrm{~min}$ caused a dose-dependent stimulation of PRL release. Infusion of 0.5 hypothalamic extract equivalent induced a $86.3 \pm 3.8 \%$ stimulation and the maximal effect was observed $10 \mathrm{~min}$ after the beginning of the infusion. Comparison between different extraction procedures of hypothalamic material $(\mathrm{HCl} 0.1 \mathrm{~N}$ or acetic acid $1 \mathrm{~N}$ ) gave the same stimulatory effect (data not shown). Repeated ad-

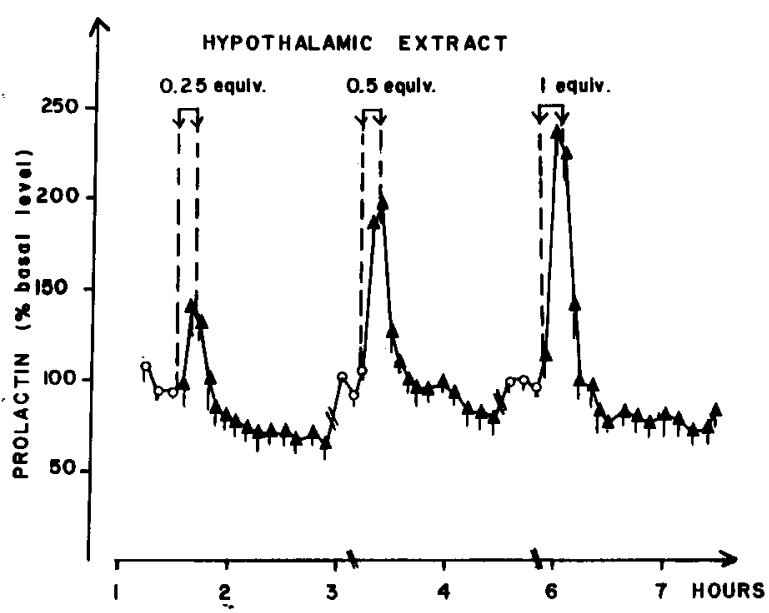

Fig. 1. Effect of increasing concentrations of trout hypothalamic extract ( $0.25-1$ equiv.) on PRL secretion by perifused trout RPD. After a 90 minute equilibration period, the extract was infused for 5 minutes. Data represent the mean \pm SEM of three independent perifusion experiments. The reference level of PRL release $(100 \%=$ basal level) was calculated for each experiment as the mean PRL secretion rate during 22.5 minutes (3 consecutive fractions $0^{----o}$ ) just preceding infusion of secretagogue.

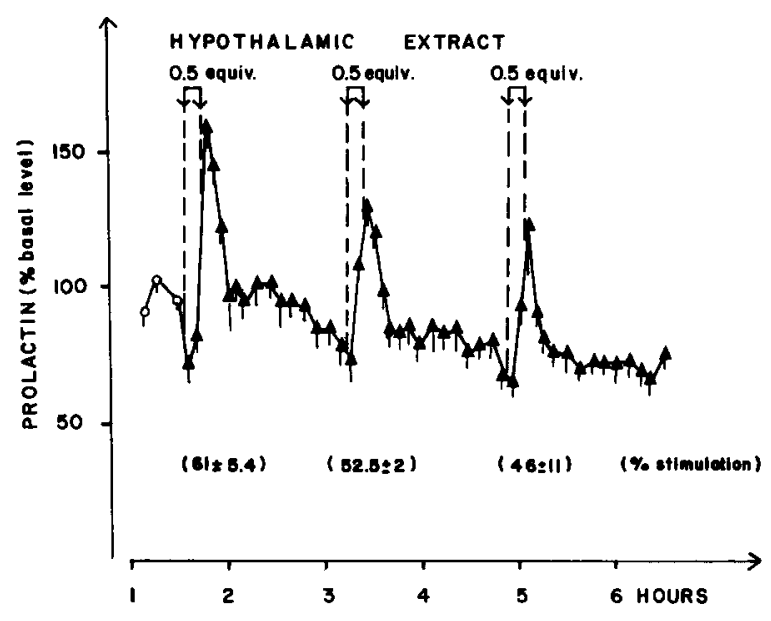

Fig. 2. Effect of repeated administration of trout hypothalamic extract ( 0.5 equiv.) on PRL secretion by perifused trout PRD. After a 90 minute equilibration period, the extract was infused for 5 minutes and twice subsequently with a $1 \mathrm{~h}$ equilibration period between each infusion of extract. Data represent the mean \pm SEM of 3 dependent perifusion experiments. See legend of Fig. 1 for further details.

ministration of the same amount of hypothalamic extract did not lead to a significant reduction of the stimulatory phase (Fig. 2). 
Table 1. Effect of different tissue extracts on PRL secreted from perifused RPD

\begin{tabular}{ll}
\hline Tissue extract & s-PRL $(\mathrm{ng} / \mathrm{ml})$ \\
\hline Muscle (0.5 equiv.) & $18.1 \pm 3.1^{\mathrm{a}}$ \\
Control (medium only) & $18.4 \pm 3.4$ \\
Liver (0.5 equiv.) & $16.1 \pm 4.4^{\mathrm{a}}$ \\
Control (medium only) & $14.2 \pm 3.1$ \\
Gut (0.5 equiv.) & $17.7 \pm 2.7^{\mathrm{a}}$ \\
Control (medium only) & $19.2 \pm 3.5$ \\
\hline
\end{tabular}

Data are shown as mean $\pm \mathrm{SEM}, \mathrm{n}=3$; ${ }^{\text {a }}$ non significantly different in comparison with respective control $(p=0.05)$.

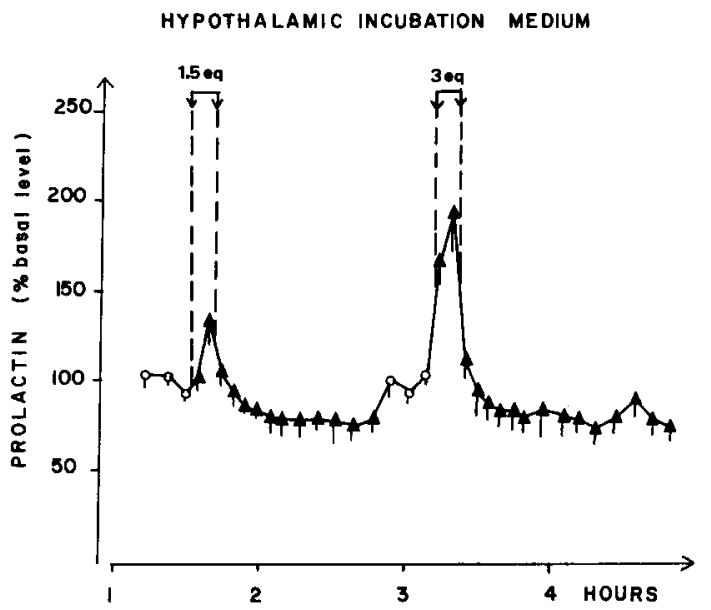

Fig. 3. Effect of trout hypothalamic extract (1 equiv.) and rat hypothalamic extract ( 1 equiv.) on PRL secretion by perifused trout RPD. After a 90 minute equilibration period, the rat extract was infused for 5 minutes. PRL secretion was allowed to stabilize for $1 \mathrm{~h}$ and the trout extract was then infused for 5 minutes. Data represent the mean \pm SEM of 3 dependent perifusion experiments. See legend to Fig. 1 for further details.

In order to confirm the specificity of this stimulatory effect we measured the amount of PRL in the infused hypothalamic extract and found no detectable level (data not shown). Moreover infusion of different tissue extracts (liver, gut, muscle) did not significantly stimulate PRL release (Table 1). On the contrary, infusion of medium from incubation of 1.5 and 3 hypothalami showed a stimulation of respectively $35.5 \pm 4.6 \%$ and $94 \pm 9.2 \%$ (Fig. 3). As shown in Fig. 4, comparison of the effect observed with hypothalamic extract (1 equivalent) from adult male rat and immature rainbow trout

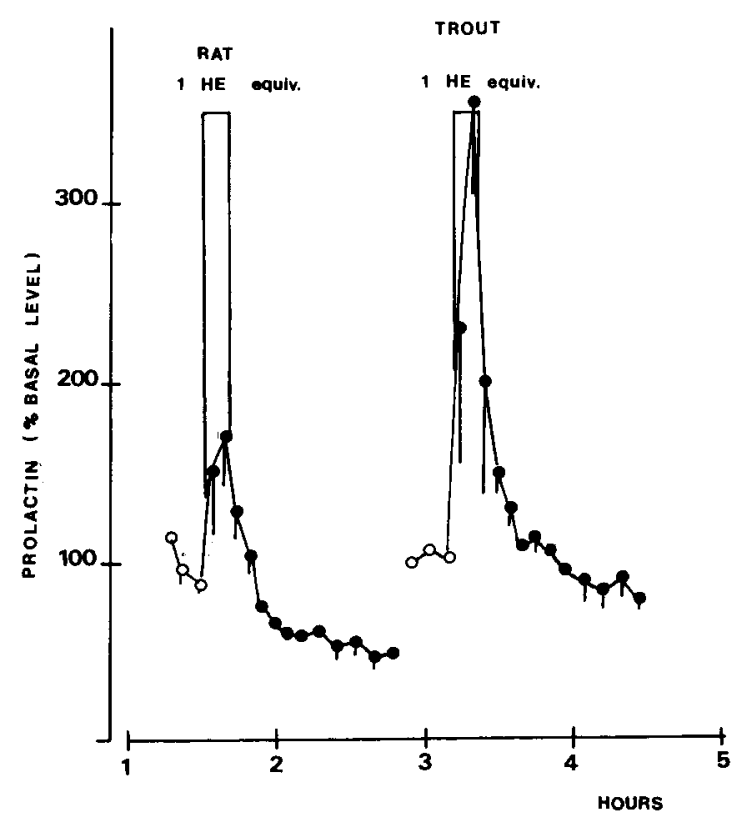

Fig. 4. Effect of medium from trout hypothalami incubations ( 1.5 and 3 hypothalami/ml) on PRL secretion by perifused trout RPD. After a 90 minute equilibration period, the hypothalami medium, (collected after a $24 \mathrm{~h}$ static incubation at $12^{\circ} \mathrm{C}$ ) was infused for 5 minutes. A $1 \mathrm{~h}$ stabilization period was allowed between the two infusions of medium. Data represent the mean \pm SEM of 3 dependent perifusion experiments. See legend to Fig. 1 for further details.

showed a $67 \%$ stimulation with the rat tissue, whereas a $254 \pm 53 \%$ stimulation was observed with the fish material.

Characterization of the hypothalamic stimulatory factors

Measurement of TRH content in rainbow trout hypothalami by RIA gave a mean value $(n=5)$ of $4.7 \pm 2.5 \mathrm{ng}$ TRH/hypothalamus which corresponds to an extract concentration of $1.64 \times$ $10^{-8} \mathrm{M}$. Furthermore, HPLC analysis of hypothalamic extracts indicated that immunoreactive TRH activity eluted as a unique peak at the same place as standard labelled TRH (Fig. 5).

Serotonin content was also estimated in rainbow trout hypothalamus. A mean value $(n=3)$ of 13 $\pm 5 \mathrm{ng}(5-\mathrm{HT}) /$ hypothalamus was obtained which corresponds to a concentration of $6.12 \times 10^{-8} \mathrm{M}$, 


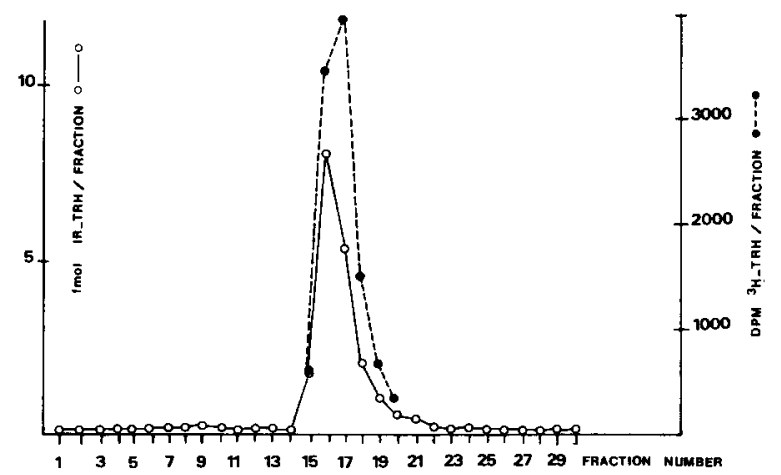

Fig. 5. HPLC of immunoreactive - TRH from trout hypothalamus extract. Elution profile of standard $\left({ }^{3} \mathrm{H}\right)-$ TRH ( $\left.\bullet---\bullet\right)$ elution profile of immunoreactive - TRH from trout hypothalamus $(0-0)$

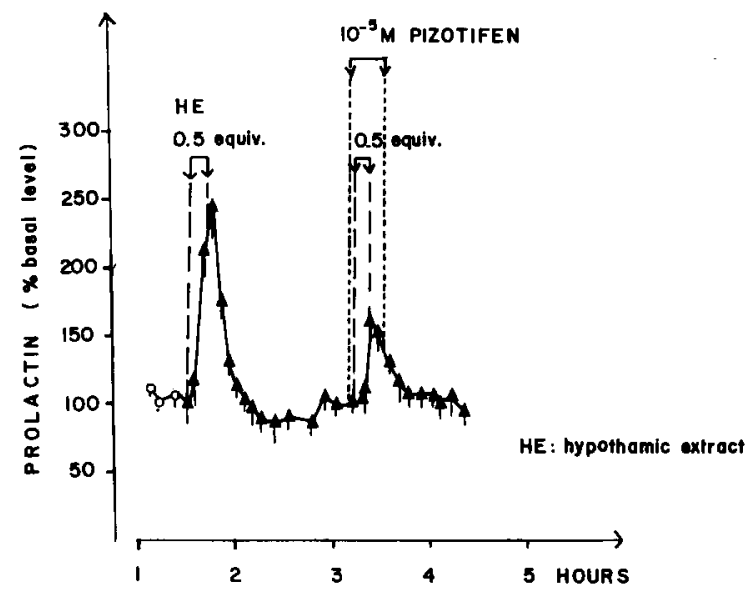

Fig. 6. Effect of trout hypothalamic extract ( 0.5 equiv.) in the presence or absence of pizotifen $\left(10^{-6} \mathrm{M}\right)$ on PRL secretion by perifused trout RPD. After a 90 minute equilibration period, the trout extract was infused for 5 minutes. PRL secretion was then allowed to stabilize for $1 \mathrm{~h}$ and pizotifen was further infused for 25 minutes. After 20 minutes hypothalamic extract was infused for 5 minutes in the presence of pizotifen. Data represent the mean \pm SEM of 3 dependent perifusion experiments. See legend to Fig. 1 for further details.

in the extract. Moreover, results presented in Fig. 6 indicated that the stimulatory effect observed after infusion of hypothalamic extract ( 0.5 equivalent) was partially blocked by pizotifen $\left(10^{-6} \mathrm{M}\right)$, a specific serotonin antagonist.

\section{Discussion}

In the present study we provide evidence using homologous perifusion (hypothalamus and pituitaries were collected from the same group of fish) that hypothalamic extracts stimulate PRL release in immature rainbow trout (Fig. 1). Moreover, the PRL secretion was proportional to the amount of hypothalamic extract infused. Adequate control experiments (Table 1) and observation of a similar stimulatory effect with hypothalamic incubation medium (Fig. 3) further supported the specificity of this effect. The observation of such stimulatory activity of fish hypothalamic extracts has also been reported in eel by Hall and Chadwick $(1978,1983)$. These authors also showed that this tissue extract stimulated PRL secretion from chicken pituitary in vitro, confirming that eel hypothalamus contained predominantly PRL releasing factors (Hall and Chadwick 1979). Using the same extraction procedure, these authors also showed that hypothalamic extract from cod (Gadus gadus) and flounder (Pleuronectes flesus) inhibited PRL secretion when tested in the same in vitro system (Hall and Chadwick 1979). Therefore, it is unlikely that the PRL release stimulatory activity observed in eel was due to the non-extraction of inhibitory factors. The tissue preparation procedure used in our study was the same as the one used in the above studies (Hall and Chadwick 1978, 1979, 1983). When we tested another tissue preparation protocol (1N acetic acid extraction) known to extract dopamine more efficiently (Hyde et al. 1987), we still observed a stimulatory effect. Rat hypothalamic extracts also stimulated PRL secretion from rainbow trout pituitaries (Fig. 4), whereas such tissue extract is known to have predominantly prolactin inhibiting capacity (Kragt and Meites 1967; Hall and Chadwick 1979; Hyde et al. 1987; Khorram and McCann 1986). These studies support the hypothesis that prolactin release inhibiting factors from rainbow trout hypothalami are not predominantly active in rainbow trout. This is in agreement with the absence of any effect of two of the principal candidates as PRL release inhibiting factors in fish (see reviews by Clarke and Bern 1980; Ball 1981; Bern 1983) when infusing dopamine or somatostatin in our perifusion system (Gonnet and Prunet, unpublished data).

The presence of a predominant PRL release stimulatory activity in hypothalamus from immature 
rainbow trout suggests that PRL release might be under stimulatory hypothalamic control in this species. This is in agreement with the observation in rainbow trout of decreasing activity of homotransplanted PRL cells (Leatherland and Lin 1976). In addition, recent studies on PRL secretion from chum salmon pituitaries during long-term incubation experiments also led to the suggestion of a stimulatory hypothalamic control of PRL release in this species (Suzuki et al. 1987). Thus, in terms of neural control of PRL release, salmonid species appear to be related to avian and reptilian species, where a similar stimulatory hypothalamic control was shown (Nicoll et al. 1970; Tixier Vidal and Gourdji 1972; Hall and Chadwick 1979; Fiorindo 1980).

The recent demonstration of a dose dependant stimulatory effect of TRH on PRL secretion from perifused rainbow trout RPD (authors', unpublished data) led us to investigate the presence of this neuropeptide in hypothalamic extracts. Using a specific RIA, a physiological amount of TRH was found in trout hypothalamus, in agreement with a similar analysis done in salmon hypothalamus (Jackson and Reichlin 1974). We observed that a dose as low as $10^{-10} \mathrm{M}$ TRH stimulated PRL secretion indicating that TRH is a very potent PRL releasing factor in immature rainbow trout (unpublished data). Furthermore, chromatographic studies of trout hypothalamus confirmed that immunoreactive trout TRH is similar to synthetic mammalian TRH (Fig. 5). This is in accordance with previous studies on fish TRH indicating TRHlike immunoreactivity and bioactivity in salmon hypothalamus and high affinity TRH receptors in goldfish pituitary gland (Jackson and Reichlin 1974; Burt and Ajam 1984). Thus, owing to the TRH concentration measured in hypothalamic extracts ( $1.64 \times 10^{-8} \mathrm{M}$; in this study) and the stimulation obtained with similar doses of mammalian TRH $\left(10^{-8} \mathrm{M}\right.$ TRH induced $200 \%$ stimulation of PRL release (author's, unpublished data), it is conceivable that the stimulatory effect observed in this study with hypothalamic extract may be accounted for by TRH, at least partially. Involvement of TRH as an important prolactin releasing factor was also suggested in other teleost species (Wigham and Batten 1984; Batten and Wigham 1984; Hall and
Chadwick 1983; Barry and Grau 1986).

We have recently observed that serotonin stimulated in vitro PRL release from perifused RPD and that serotonin was acting directly on PRL cells as the neuroamine was still active on perifused isolated cells. In the present study physiological levels of serotonin were measured in hypothalamic extract. The stimulatory effect observed when infusing hypothalamic extract is partially inhibited by pizotifen, a specific serotonin antogonist (Fig. 6; authors', unpublished data). These results support the involvement of serotonin as another important PRL releasing factor in rainbow trout. Previous studies have demonstrated that serotonin stimulates PRL secretion in fish (Olivereau and Olivereau 1979; Olcese et al. 1979; James and Wigham 1984). Moreover, immunoreactive serotonin-containing cells together with fibers were localized in different regions of fish pituitary gland and brain (Goves and Batten 1985; Margolis-Kazan et al. 1985; Kah and Chambolle 1983). Although labelled cells or fibers were not observed in the PRL cell region, Groves and Batten (1985) suggested a neurovascular neural route of action for serotonin in the proximal pars distalis. Thus, our results are the first to demonstrate that serotonin is a major contributor of PRL releasing activity of rainbow trout hypothalamus.

In conclusion, this study suggests that PRL secretion in immature rainbow trout is under stimulatory control by the hypothalamus, and that serotonin and probably TRH are two important PRL releasing factors involved in this hypothalamic control. In salmonid species (this study; Suzuki et al. 1987) control of PRL secretion appears to be different to what has been reported in other teleost species where a primary inhibitory control by the hypothalamus has been shown (reviewed by Clarke and Bern 1980; Ball 1981; Bern 1983). It seems, however, more likely that a dual control of PRL exists in immature rainbow trout with stimulatory factors predominanting over inhibitory factors and it is possible that this proportion may reverse under different physiological conditions. Thus, in this species characterization of PRL release inhibiting factors requires further investigation. 


\section{Acknowledgements}

We express our gratitude to Dr. M.C. Tonon and Dr. H. Vaudry for much helpful discussion. We thank J. Hall for critical review of the manuscript. Gratitude is also expressed to V. Ploteau and C. Connan for typing the manuscript.

\section{References cited}

Ball, J.N. 1981. Hypothalamic control of the pars distalis in fishes, amphibians, and reptiles. Gen. Comp. Endocrinol. 44: $135-170$.

Ball, J.N., Baker, B.I., Olivereau, M. and Peter, R.E. 1972. Investigation of hypothalamic control of adenohypophysial functions in teleost fishes. Gen. Comp. Endocrinol. 3: 11-21.

Batten, T.F.C. and Ball, J.N. 1977. Ultrastructure of the neurohypophysis of the teleost Poecilia formosa in relation to neural control of the adenohypophysial cells. Cell Tiss. Res. 185: 409-433.

Batten, T.F.C. and Wigham, T. 1984. Effect of TRH and somatostatin on release of prolactin and growth hormone in vitro by the pituitary of Poecilia latipinna. Cell Tiss. Res. 237: 595-603.

Barry, T. and Grau, E.G. 1986. Estradiol $17 \beta$ and thyrotrophin releasing hormone stimulate prolactin release from the pituitary gland of a teleost fish in vitro. Gen. Comp. Endocrinol. 62: $306-314$.

Burgus, M. and Rivier, J. 1977. Application of high pressure liquid chromatography to peptides. In Proc. 5th Ann. Pept. Symp. pp. 52-54. Edited by M. Goodman and J. Meien Hofer. Wiley, New York.

Burt, D.R. and Ajan, M.A. 1984. TRH receptors in fish. Gen. Comp. Endocrinol. 53: 135-142.

Clarke, W.C. and Bern, H.A. 1980. Comparative endocrinology of prolactin. In Hormonal Proteins and Peptides. Vol. VIII. pp. 105-197. Edited by C.H. Li. Academic Press, New York.

Fiorindo, R.P. 1980. Further evidence for a prolactin-stimulating neurohormone in reptiles. Gen. Comp. Endocrinol. 40: $52-58$.

Follenius, E. 1972. Cytologie fine de la dégénérescence des fibres aminergiques intrahypophysaires chez le poisson téléosteen Gasterosteus aculeatus après traitement par la 6-hydroxydopamine. Z. Zellforsch. 128: 69-82.

Gonnet, F., Prunet, P., Tonon, M.C., Dubourg, P., Kah, O. and Vaudry, H. 1988a. Effect of osmotic pressure on prolactin release in rainbow trout: in vitro studies. Gen. Comp. Endocrinol. 69: 252-261.

Graffeo, A.B. and Karger, B.N. 1976. Analysis of indol compounds in urine by high performance liquid chromatography with fluorometric detection. Chim. Chem. 22: 184-187.

Grau, E.G., Nishioka, R.S. and Bern, H.A. 1982. Effect of somatostatin and urotensin II on tilapia pituitary prolactin release and interaction between somatostatin, osmotic pressure, $\mathrm{Ca}^{+}+$and adenosine $3^{\prime}, 5^{\prime}$-monophosphate in prolactin release in vitro. Endocrinology 110: 910-915.

Grouselle, D., Tixier-Vidal, A. and Pradelle, P. 1982. A new improvement of the sensitivity and specificity of radioimmunoassay for thyroliberin. Application to biological samples. Neuropeptides 3: 29-33.

Hall, T.R. and Chadwick, A. 1978. Control of prolactin and growth hormone secretion in the eel Anguilla anguilla. Gen. Comp. Endocrinol. 36: 388-395.

Hall, T.R. and Chadwick, A. 1979. Hypothalamic control of prolactin and growth hormone secretion in different vertebrate species. Gen. Comp. Endocrinol. 37: 333-342.

Hall, T.R. and Chadwick, A. 1983. The effect of thyrotrophin releasing hormone on secretion of prolactin and growth hormone from eel pituitaries incubated in vitro. ERCS Med. Sci. 11: $1009-1010$.

Hirano, T., Prunet, P., Kawauchi, H., Takahashi, A., Kubota, J., Nishioka, R.S., Bern, H.A. and Ishii, S. 1985. Development and validation of a salmon prolactin radioimmunoassay. Gen. Comp. Endocrinol. 59: 266-276.

Holmes, R.L. and Ball, J.N. 1974. The Pituitary Gland. A Comparative Account. Cambridge Univ. Press, New York.

Hyde, J.F., Murai, I. and Ben-Jonathan, N. 1987. The rat posterior pituitary contains a potent prolactin-releasing factor: studies with perifused anterior pituitary cells. Endocrinology 121: 1531-1539.

Jackson, I.M.D. and Reichlin, S. 1974. Thyrotrophin releasing hormone (TRH): distribution in hypothalamic and extra hypothalamic brain tissues of mammalian and submammalian chordates. Endocrinology 95: 854-862.

James, V.A. and Wigham, T. 1984. Evidence for dopaminergic and serotininergic regulation of prolactin cell activity in the trout Salmo gairdneri. Gen. Comp. Endocrinol. 56: 231-239.

Kah, O., Dubourg, P., Onteniente, B., Geffard, M. and Calas, A. 1986. The dopaminergic innervation of the goldfish pituitary. Cell. Tiss. Res. 244: 577-582.

Khorram, O. and McCann, S.M. 1986. On the presence of a nondopaminergic, peptidergic prolactin release inhibiting factor in hypothalmic extracts of infantile rats. Neuroendocrinology 44: 65-69.

Kragt, C.L. and Meites, J. 1967. Dose response relationships between hypothalamic PIF and prolactin release by rat pituitary tissue in vitro. Endocrinology 80: 1170-1173.

Leatherland, J.F. 1970. Histological investigation of pituitary homotransplants in the marine form (trachurus) of the threespine stickleback, Gasterosteus aculeatus L. Z. Zellforsch. 104: 337-344.

Leatherland, J.F. and Lin L. 1976. Fine structure of the rostral pars distalis follicle cells in homotransplanted pituitaries of rainbow trout, Salmo gairdneri. Can. J. Zool. 54: 122-132.

Nagahama, Y., Nishioka, R.S. and Bern, H.A. 1974. Structure and function of the transplanted pituitary in the seawater goby, Gillichthys mirabilis. I. The rostral pars distalis. Gen. Comp. Endocrinol, 22: 21-34. 
Nagahama, Y., Nishioka, R.S., Bern, H.A. and Gunther, R.L. 1975. Control of prolactin secretion in teleosts, with special reference to Gillichthys mirabilis and Tilapia mossambica. Gen. Comp. Endocrinol. 25: 166-188.

Nicoll, C.S., Fiorindo, R.P., McKennee, C.T. and Parsons, J.A. 1970. Assay of hypothalamic factors which regulate prolactin secretion. In Hypophysiotropic Hormones of the Hypothalamus. pp. 115-144. Edited by J. Meites. Williams and Wilkins, Baltimore.

Oliese, J.M., Hall, T.R., Fiqueroa, H.R. and de Vlaming, V.L. 1979. Hypothalamic monamine oxidase, a component in the serotoninergic control of pituitary prolactin content in Carassius auratus L. Gen. Comp. Endocrinol. 38: 309-313.

Olivereau, M. 1975. Dopamine, prolactin control, and osmoregulation in eels. Gen. Comp. Endocrinol. 26: 550-561.

Olivereau, M. and Olivereau, J. 1979. Effect of serotonin on prolactin and MSH-secreting cells in the eel, comparison with the effect of 5-hydroxytryptophan. Cell Tiss. Res. 196: 397-408.

Peter, R.E. and Fryer, J.N. 1983. Endocrine functions of the hypothalamus of Actinopterygians. In Fish Neurobiology. Vol. 2. pp. 165-201. Edited by R.E. Davis and R.G. Northcutt. Univ. of Michigan Press, Ann Arbor.

Prunet, P., Boeuf, G. and Houdebine, L.M. 1985. Plasma and pituitary prolactin levels in rainbow trout during adaptation to different salinities. J. Exp. Zool. 235: 187-196.

Sage, M. 1966. Organ culture of teleost pituitaries. J. Endocrinol. 34: IX-X.

Schreibman, M.P. and Holtzman, S. 1975. The histophysiol- ogy of the prolactin cell in non-mammalian vertebrates. Am. Zool. 15: 867-880.

Suzuki, R., Kishida, M., Ogasawara, T., Hasegawa, S. and Hirano, T. 1987. Prolactin and growth hormone secretion during long term incubation of the pituitary pars distalis of mature chum salmon, Oncorhynchus keta. Gen. Comp. Endocrinol. 68: 76-81.

Tixier-Vidal and Gourdji, D. 1972. Cellular aspects of the control of prolactin secretion in birds. Gen. Comp. Endocrinol. Suppl. 3: 51-64.

Wigham, T., Ball, J.N. and Ingleton, P.M. 1975. Secretion of prolactin and growth hormone by teleost pituitary in vitro. III Effect of dopamine on hormone release in Poecilia latipinna. J. Comp. Physiol. 104B: 87-96.

Wigham, T. and Batten, T.F.C. 1984. In vitro effects of thyrotrophin releasing hormone and somatostatin on prolactin and growth hormone release by the pituitary of Poecilia latipinna. I. An electrophoretic study. Gen. Comp. Endocrinol. 55: 444-449.

Wigham, T., Nishioka, R.S.D. and Bern, H.A. 1977. Factors affecting in vitro activity of prolactin cells in the euryhaline teleost Sarotherodon mossambicus (Tilapia mossambica). Gen. Comp. Endocrinol. 32: 120-131.

Zambrano, D., Clarke, W.C., Hawkins, E.F., Sage, M. and Bern, H.A. 1973/1974. Influence of 6-Hydroxydopamine on hypothalamic control of prolactin and ACTH secretion in the teleost fish: Tilapia mossambica. Neuroendocrinology 13: 284-298. 